\title{
1 A dyrosaurid from the Paleocene of Senegal
}

3 Jeremy E. Martin ${ }^{1}$, Raphaël Sarr ${ }^{2}$, Lionel Hautier ${ }^{3}$

4

$5 \quad{ }^{1}$ Univ. Lyon, ENS de Lyon, Université Claude Bernard Lyon 1, CNRS, UMR 5276

6 Laboratoire de Géologie de Lyon: Terre, Planètes, Environnement, F-69342 46 Allée d'Italie, 7 Lyon, France.

$8 \quad{ }^{2}$ Laboratoire de Sédimentologie et Biostratigraphie, Département de Géologie, Université

9 Cheikh Anta Diop de Dakar, Sénégal

$10{ }^{3}$ Institut des Sciences de l'Evolution, UMR5554, CNRS, IRD, EPHE, Université de 11 Montpellier, Montpellier, France.

Running Header: Paleocene dyrosaurid from Senegal

Abstract.-We describe a partial dyrosaurid skeleton recently prepared out of a limestone block discovered in the 1930s from Danian strata along the Atlantic coast of Senegal. The specimen, from a single individual, comprises nicely preserved elements of the appendicular and axial skeleton from the abdominal and sacral region, which enables us to refine our knowledge on some postcranial characteristics of the Dyrosauridae. Although Dyrosauridae are abundant in early Eocene deposits of North Africa, the present discovery in the Danian of Senegal fills a patchier record early after the K/Pg boundary and provides an important comparative datapoint with the few other Danian dyrosaurid records such as Atlantosuchus from nearby Morocco or Guarinisuchus and Hyposaurus from Brazil and the USA, respectively. 


\section{Introduction}

The Dyrosauridae represent a monophyletic group of crocodylomorphs that radiated in the marine environment during the Cretaceous. Their earliest record dates from the Late Cretaceous with mentions from the Campanian (Churcher and Russel, 1992; Lamanna et al. 2004; Kear et al. 2008; Salih et al. 2015) or from undetermined Late Cretaceous levels (Sertich et al. 2006) and perhaps from levels as old as the Cenomanian (Buffetaut and Lauverjat, 1978). The group survived through the end Cretaceous biological crisis and became extinct during the early Eocene, most probably during the Ypresian (Buffetaut, 1978a; Buffetaut, 1982; Hill et al. 2008; Martin et al. 2014). Accounts of dyrosaurid remains in the Lutetian (Pilgrim, 1940; Tessier, 1952; Buffetaut, 1978a, b) should be re-evaluated in view of recent stratigraphic studies (e.g. O'Leary et al. 2006) before they can be validated or not. Although the fossil record of dyrosaurids is especially abundant with relatively complete specimens from the late Paleocene (Buffetaut, 1980; Jouve, 2007) and early Eocene (Bergounioux, 1956; Buffetaut, 1978a; Jouve, 2005), fewer representatives from the early Paleocene have been reported so far. They include genera such as Hyposaurus from the Danian of the USA (Troxell, 1925; Denton et al. 1997), Atlantosuchus from the Danian of Morocco (Buffetaut, 1979; Jouve et al. 2008) and Guarinisuchus from the Danian of Brazil (Barbosa et al. 2008). The genus Phosphatosaurus has been reported from Mali and Niger and may also be Danian in age according to Buffetaut (1978a). Other fragmentary finds from Bolivia (Buffetaut, 1991), Brazil (Cope, 1886), Pakistan (Buffetaut, 1977) and Senegal 49 (Tessier, 1952) have been attributed a Danian or early Paleocene age. Current data indicate that dyrosaurid diversity was lower during the Late Cretaceous than during the Paleocene (6 
genera versus 11, respectively). On the other hand, the diversity of dyrosaurids during the Cretaceous may parallel that of the Paleocene depending on phylogenetic resolution within Dyrosauridae (Hill et al. 2008). Some authors have proposed that this could be explained by a shift with the extinction of Cretaceous predators such as mosasaurs freeing space for dyrosaurids (Jouve et al., 2008; Barbosa et al. 2008). Nevertheless, such diversity counts merge the dyrosaurid fossil record of the entire Paleocene, and dyrosaurid diversity immediately after the $\mathrm{K} / \mathrm{Pg}$ crisis is poorly known and difficult to evaluate. Records of large vertebrate predators immediately after the $\mathrm{K} / \mathrm{Pg}$ boundary are equally important as those from the Maastrichtian because they may provide insights into the reorganization of marine foodwebs following a major biotic disruption.

Here, we describe a dyrosaurid specimen collected in the 1930s by two French geologists, Fernand Jacquet and Maurice Nicklès, who both worked for the Service Géologique de l'Afrique Occidentale Française (AOF) in Dakar. Their survey of Paleogene outcrops along the Atlantic coast of Senegal led to the discovery, near the village of Poponguine (Fig. 1), of the presently described specimen, which has been briefly mentioned in several notes (Malavoy, 1934 p.7; 1935 p. 7; Jacquet, 1936). The specimen consists of articulated postcranial elements belonging to a single individual, the bones of which were deposited in a low energy marine environment of Danian age according to associated microfossils.

History of the discovery.-Before we borrowed the specimen for preparation and study, the following inscription was visible on the surface of the sediment: "Poponguine - Sénégal, Falaise du Bungalow" (Fig. 3). "La Falaise du Bungalow" is a small seaside cliff subjected to wave erosion and made of an alternating sequence of marls and limestones (see geological 
section). Nowadays, the Presidential residence is sitting on top of it, having replaced the bungalow of the "Gouverneur général de l'Afrique Occidentale Française".

A note from the head of the Service géologique de l'AOF indicates 1934 as the year of the discovery of the Poponguine specimen, originally identified as a fossil mammal with eight vertebrae, three elongate bones and six ribs (Malavoy, 1934). The following year, the same specimen was identified as a crocodile from Poponguine (Malavoy, 1935). Jacquet (1936), reporting on some debris of a marine crocodylian, provided a brief context for the specimen indicating a provenance from alternating levels of marls and limestones from Poponguine. $\mathrm{He}$ attributed the deposits to be early Eocene in age on the basis of their invertebrate content, although more recent studies consider the deposits to be Danian in age (see geological section). Following the tragic loss in 1937 of F. Jacquet during a field survey in Mauritania, M. Nicklès was put in charge of handling the works of his colleague (Legoux, 1937). A few years later, Arambourg and Joleaud (1943 p. 63) mentioned that M. Jacquet recovered vertebrae and limb bones belonging to Dyrosaurus in the area of Poponguine. Tessier (1952) mentions that this material has been observed by C. Arambourg, citing "1943 Dyrosaurus sp. Arambourg (6), p. 63" and referring to the collection Jacquet of the MNHN (Muséum National d'Histoire Naturelle, Paris). Therefore, the specimen must have been part of the MNHN collections at least until 1952 but it is unclear when the specimen was transferred from Dakar to Paris. From this date, the whereabouts of the specimen become unknown and no mention of it is made in the literature. The specimen re-surfaces much later in Toulouse. The dyrosaurid specimen was stored in the collections of the Institut Catholique de Toulouse from an unknown date until the mid 90s when it was donated to the Toulouse Museum (MHNT) on September 091996 (Y. Laurent, pers. comm.). Understanding how the specimen transited from MNHN Paris to Toulouse is unclear at this stage and we can only speculate on potential links between Camille Arambourg (1885-1969), then Professor at MNHN who 
made the observations on the specimen (see above), and Frédéric-Marie Bergounioux (1900-

101 1983), paleontologist and theologist at the Institut Catholique de Toulouse. Both researchers

102 knew each other, with C. Arambourg having sent to F-M. Bergounioux several fossil turtle

103 specimens for study (Bergounioux, 1952). It is therefore possible that the dyrosaurid

104 specimen arrived at the collections of Toulouse in this way. However, no mention of the

105 Poponguine specimen is made in Bergounioux' monograph, which extensively describes

106 dyrosaurid material from Tunisia (Bergounioux, 1956).

107

\section{Geological setting}

110 Paleocene strata crop out on a narrow littoral stretch between Toubab Dialaw until the

111 southern end of the horst of Diass (Fig. 1). Most of the outcrops are represented by alternating

112 marls and limestones, which take part in the Ndayane Formation. This formation is overlain

113 by discording shelly limestones of the Poponguine Formation, which crop out East of

114 Poponguine. The Ndayane Formation is visible in a cliff, the altitude of which is less than 10

$115 \mathrm{~m}$ above sea level. The Ndayane Formation uncomformably overlies the Maastrichtian gritty

116 limestone containing ammonites with a conglomeratic level (Castelain et al. 1965). A

117 lithological section along the stretch of coastline shows the following units totalling $27 \mathrm{~m}$ in 118 thickness:

119 From the base, grey argillaceous limestone becomes replaced by lenticular limestone

120 (2.5 m thick) with gypsum veins;

121 Most of the cliff (17.5 m thick) is made of limestone beds alternating with yellowish

122 marly limestones with gypsum veins. The limestone beds become thicker in the median

123 section of the cliff and the marly limestone beds become lenticular. Near the summit,

124 limestone beds become thinner whereas marly-limestone beds become thicker. 
126 limestones ( $7 \mathrm{~m}$ thick).

128 and benthic foraminifers as well as ostracods. These microfaunas have been studied by

129 several authors (Castelain et al., 1965; Faye, 1983; Sarr, 1995; Sarr and Ly, 1998; Sarr, 1998)

130 who established a middle to upper Danian age for the formation on the basis of the following

131 planctonic foraminifer species, also identified here in sediment associated with

132 MHNT.PAL.2012.0.45: Chiloguembelina morsei (Kline), Morozovella inconstans, $M$.

133 pseudobulloides (Plummer), M. cf. trinidadensis (Bolli), and Planorotalites compressa

134 (Plummer) (Fig. 2). This age is in agreement with that established by Tessier (1952) on the

135 basis of macrofaunas.

136 The depositional environment corresponds to a middle to external platform with a water depth

137 comprised between 100 and $150 \mathrm{~m}$ ) with a muddy bottom covered with algae, receiving

138 episodically coarse material from the infralittoral environment (Sarr, 1998).

140 Systematic Paleontology

141

147 Description.-The specimen was preserved as three blocks (Fig. 3.1), which underwent acid
Crocodylomorpha Hay, 1930

Dyrosauridae De Stefano, 1903

Dyrosauridae indet.

Figures 3-10 preparation (Fig. 3.2). The largest block was prepared so that most elements of the specimen preserve their articulation. Several elements were totally freed from the matrix and could be 
150 described individually. The main block preserves the last five thoracal vertebrae (\#11 to \#15);

151 thoracal vertebra \#10 has been freed from the matrix as well as two other thoracal vertebrae

152 (one being heavily weathered and the other only consisting of the centrum) thus totalizing

153 eight thoracic vertebrae. The two sacral vertebrae are preserved on the main block. The

154 second sacral vertebra is split in half and is loose from the main block (Fig. 4). Four caudal

155 vertebrae are also available. The right ischium is firmly connected to a fragmentary ilium

156 (Fig. 5). The right femur (Fig. 6) is preserved and is slightly displaced from the pelvic area.

157 The articulated vertebrae are positioned within a mix of ribs, gastralia, and displaced dorsal

158 and ventral osteoderms.

160 Materials.-MHNT.PAL.2012.0.45, postcranial elements of a single specimen from the

161 abdominal and sacral region.

162

163 Thoracal vertebrae.-The anteriormost thoracal vertebra is complete (Fig. 4.1-5) and

164 corresponds to thoracal vertebra \#10. In anterior or posterior views, the amphicoelous

165 centrum has a subquadrangular outline, being nearly higher than wide. The posterior margin

166 of the centrum displays a pathological area near its anterolateral corner, which may

167 correspond to an erosive lesion (arrow in Fig. 4.2). The centrum is slightly elongated, being

168 longer than high. In lateral view, the ventral margin of the centrum is faintly concave. The

169 main corpus of the centrum is slightly constricted laterally with thick anterior and posterior

170 margins that define the limits of the anterior and posterior surfaces. The neurocentral suture is

171 visible and runs transversally along the lateral margin of the centrum, in its dorsal half. A

172 distinct and shallow circular pleurocoele spreads over the centrum and neural arch, below the

173 posterior margin of the transverse process. The neural arch is robustly attached to the

174 centrum. The neural spine is relatively short, being nearly as high as the centrum. Its dorsal 
margin is straight and represents half the length of the centrum. The dorsal surface of the

176 neural spine is vascularized. In anterior and posterior views, the neural arch shows an

177 extensive medial sulcus. The neural canal is heart-shaped in cross-section with its dorsal

178 margin receiving a ventrally projecting lamina at the level of the neural spine. The anterior

179 extent of the prezygapophyses is almost in line with the anterior margin of the centrum,

180 whereas the posterior extent of the postzygapophyses project far beyond the posterior margin

181 of the centrum. The articular faces on the pre- and postzygapophyses are obliquely oriented

182 with respect to the neural spine. The laminar transverse processes are short and comparable in

183 dimensions to the centrum width, but their anteroposterior length is slightly shorter than the

184 length of the centrum. In dorsal view, the distal margin of the transverse processes is unequal

185 with a parapophysis shorter than the diapophysis.

186

187 Sacrum.-The anterior part of the first sacral vertebra is connected to the rest of the vertebral

188 column and is partly embedded in the sediment. The second sacral vertebra detached during

189 preparation, revealing a strong sutural surface. Much like Hyposaurus (Schwarz et al., 2006),

190 the two sacral vertebrae appear to have not fused together, whereas these bones are fused in

191 Dyrosaurus sp. (Schwarz et al., 2006). The anterior and posterior surfaces of the sacral centra

192 are ovoid in outline, being wider than tall. The sutural surface of the anterior margin of the

193 second sacral vertebra is complex and presents two parallel sulci along its midline (Fig. 4.6).

194 Such similar sulci have previously been reported on the posterior, but not anterior, surface of

195 the second sacral vertebra of D. phosphaticus and of Hyposaurus (YPM 753) by Schwarz et

196 al. (2006). The second sacral vertebra can be observed in ventral aspect and no obvious

197 shallow sulcus is observed here close to its anterior margin, contrary to the condition in

198 Dyrosaurus sp. and cf. Rhabdognathus (Schwarz et al. 2006). As observed in dorsal view, the

199 first and second sacral ribs are hourglass shaped. The sacral ribs of the first sacral vertebra are 
about twice as long as the ribs of the second sacral vertebra (Figs. 3, 4.8), as is commonly

201 observed among crocodylians. The first sacral rib occupies the anterior two thirds of the

202 lateral surface of the centrum length, whereas the second sacral rib occupies the entire length

203 of the centrum. On the first sacral vertebra, as observed in posterior view, a distinct circular

204 fossa is visible at the sutural intersection of the neural arch, centrum and sacral rib. As in

205 Dyrosaurus sp., the proximal insertion of the sacral rib for the second sacral vertebra is

206 restricted to the corpus of the second sacral centrum (Schwarz et al. 2006) and unlike the

207 condition in Rhabdognathus where the sacral rib overlaps on the centrum of the first caudal

208 vertebra (Langston, 1995). The iliac symphyseal surface of the first rib does not exceed the

209 anterior and posterior margins of the centrum. An anterolateral process is present as in

210 Dyrosaurus sp. and cf. Rhabdognathus (Schwarz et al. 2006). In lateral view, the anterolateral

211 process is thin and shows a concave articular surface; the posterior articular process of the rib

212 is located more medially than the anterolateral process and is nearly as tall as the centrum

213 height, being concave. The iliac symphyseal surface of the second sacral rib is slightly smaller

214 and symmetrical to the first sacral rib, with a tall anterior surface and a thin posterior process.

215 This iliac symphyseal surface exceeds slightly the posterior margin of the second sacral

216 vertebra. The neural spines have weathered out in the described specimen.

218 Caudal vertebrae.-At least three caudal vertebrae were prepared out of the second block.

219 Schwarz et al. (2006) described shallow bowl-shaped fossae on the anterior and posterior

220 surfaces of the centrum of the caudal vertebrae. Here, such fossae are also observed on both

221 thoracal and caudal vertebrae. The first caudal vertebra possesses no facets for the haemal

222 arches (Figs. 4.14, 4.15). The second caudal vertebra possesses a facet for the haemal arches

223 only on the posteroventral margin of its centrum (Figs. 4.19, 4.20). The third caudal vertebra

224 possesses articular facets for the haemal arches both on the anteroventral and posteroventral 
margins of its centrum (Fig. 4.21). This pattern of articulation between caudal centra and

226 haemal arches differs from that described in Dyrosaurus sp. and cf. Rhabdognathus where the

227 facet is present on the anteroventral surface from the second vertebra (Langston, 1995;

228 Schwarz et al. 2006). It is, however, similar to Congosaurus bequaerti where this pattern of

229 articulation starts from the third caudal vertebra (Schwarz et al. 2006). The first caudal

230 vertebra has proportions of the centrum similar to the sacral vertebrae; from the second caudal

231 vertebra, the centrum is longer than high with a quadrangular outline of the anterior and

232 posterior margins; the posteroventral margin is also distinctly lowered than the anteroventral

233 margin (compare Figs. 4.15, 4.20, 4.21).

Ischium.-The nearly complete right ischium is preserved in connection with the ilium in the main block (Figs. 3, 5, 5.7, 5.8, 5.9). The left ischium was isolated during preparation; it is eroded on its medial surface and misses its distal blade (Fig. 5.5, 5.6). The ischium measures about $100 \mathrm{~mm}$ in its maximum length, the blade representing about 70 percent of this length.

The anterior and posterior margins of the blade are parallel and do not seem to expand

240 significantly near the distal end of the blade, but this area is damaged. The medial surface of

241 the right element is smooth and gently concave. The broken blade of the left element shows 242 that the anterior margin is thinner than the posterior margin.

243 The proximal portion of the ischium shows the distinct acetabular foramen, which is

244 bordered anteriorly by the forward-projecting anterior iliac process and posteriorly by the

245 posterior iliac process. The anterior margin of the anterior iliac process is vertical and bears in 246 its lower half an anteriorly oriented pubic process. The pubic process sends a short spiny 247 ventral projection, resulting in a markedly concave margin. The facet for accommodating the 248 ilium is flat and obliquely oriented. On the posterior iliac process, the dorsal facet for the 249 ilium is concave, pierced by foramina and bordered by a thin bony rim; its lateral portion is 
shorter than the medial portion, matching the triangular outline of the connecting ilium.

251 Anterior to this facet, there is a flat surface that descends within the acetabulum and corresponds to the articular area for the femoral head (in lateral view, this gives to the posterior iliac process, a truncated outline). The anterior region of the acetabulum, at the level of the anterior iliac process, is anterolaterally depressed. In the same area but near the medial border, the margin is faintly crested. As seen in posterior view, the posterior iliac process possesses a short but distinct muscle scar near its proximal end (Fig. 5.9)

Ilium.-The right ilium measures $67 \mathrm{~mm}$ in its maximum height, is connected to the ischium in the main block (Fig. 3) but is heavily damaged. The left ilium is complete, although its 260 internal surface is slightly eroded (Figs. 5.1, 5.2, 5.3, 5.4). The anterior process of the ilium is massive and projects dorsally whereas it projects anteriorly in Congosaurus. Just below it, the supraacetabular crest is well defined as a thin ridge delimiting the anterodorsal outer margin of the acetabulum. The anterior peduncle of the ilium is mediolaterally thin with the ischial facet, although eroded, facing ventromedially. The posterior peduncle is massive, D-shaped in ventral view and the ischial facet is here facing fully ventrally. The acetabulum occupies 266 about one third of the lateral surface of the bone and nearly reaches the dorsal surface. The acetabular foramen is large and occupies more space than in Congosaurus. The posterior blade of the ilium is concave on its lateral surface, and in dorsal view, the ilium is sigmoidal. Except near the anterior spine, the dorsal margin of the blade is widely convex (not waspwaisted), and is indented for muscle attachment. The posteroventral margin of the blade bears 271 strong indentations, especially on the medial surface. The dorsal and ventral margins of the blade merges into a short peduncle projecting posteriorly. The ventral margin between the posterior peduncle and the strong indented area is smooth and concave on the lateral side. 
275 Femur.-The right femur preserves much of the femoral head and a proximal portion of the 276 shaft. The left femur is complete and partly connected to the block (Fig. 6). The femur has a 277 general sigmoid curvature with a strongly medially bent femoral head, a thick shaft, ovoid in 278 section and terminated distally with a pair of massive and ventrally directed condyles. In 279 proximal view, the femoral head is ovoid being wider than high. On its dorsal surface, an 280 anomalous depression filled with sediment is visible (star in Fig. 6.2). The medial most 281 outline of the femoral head is distinctly set apart from the main shaft as originally observed in 282 Hyposaurus (Troxell, 1925). The ventral margin close to the femoral head possesses a small 283 but distinct knob, which sits on the proximal part of an acute ridge that marks the 284 ventrolateral margin of the femoral head. This ridge merges with the lateral margin of the 285 shaft, which is straight and also acute until the level of the fourth trochanter. Dorsal to this 286 ridge, the lateral surface of the femur bears a large depressed zone (Figs. 6.2, 6.7) but is also 287 heavily weathered. At this level, a process is visible on the dorsal surface (Fig. 6.2, 6.7). The 288 fourth trochanter is prominent and is projecting ventrally. Dorsal to it, a shallow ovoid surface 289 corresponds to the caudofemoral flange, which faces fully medially. From this level, and as 290 seen in medial or lateral view, the shaft gently bends ventrally with two massive condyles that 291 project strongly ventrally toward the distal extremity of the shaft. The distal portion of the shaft is largely hidden by an osteoderm. In ventral view, a wide intercondylar fossa is present

293 (Fig. 6.4), which separates a narrow medial condyle from a more massive lateral condyle (Fig. 294 6.5). The medial surface of the medial condyle is flat and the condyle expands as a narrow 295 outgrowth dorsally, giving to the dorsal surface of the femur an uneven outline. The lateral 296 condyle is sturdy and possesses a slight projection on its convex lateral margin.

298 Tibia.-The proximal epiphysis of a left tibia is preserved and is bent from the shaft in a 299 posteromedial direction (Fig. 6). The proximal end is $45 \mathrm{~mm}$ mediolaterally by $41 \mathrm{~mm}$ 
anteroposteriorly, and the oval shaft, as preserved is much thinner being $20 \mathrm{~mm}$

mediolaterally by $18 \mathrm{~mm}$ anteroposteriorly. It strongly resembles another indeterminate

surface possesses two articular facets that are continuous on the medial and posterior margins.

305 Both facets are separated by a marked posterior cleft (Figs. 6.9, 6.11). The medial articular

306 facet is about twice larger and markedly concave in comparison to the posterior one. The

307 anterior margin of the articular surface is straight and does not show an articular facet. In

308 anterior view, the medial facet is angled relative to the rest of the proximal margin of the

309 tibia, giving to the shaft a strongly concave medial margin. Conversely, the lateral margin is

310 straight and nearly perpendicular with the articular surface (Fig. 6.10). Here, the cnemial crest

311 is not particularly standing out, being distinct only in its most proximal portion where a step-

312 like process accommodates the proximal margin of the fibula (Figs. 6.9, 6.11). A 9 mm long

313 ovoid depression is observed on the anterolateral corner of the tibia (Fig. 6.8), as previously

314 observed in the tibia of Guarinisuchus munizi (Sena et al. 2017, fig. 3M).

316 Calcaneum.-A complete left calcaneum is preserved (Fig. 7). The anterior ball is

317 demarcated from the posterior tuber by an extensive medial channel that runs along most of

318 the medial surface of the posterior tuber, just posterior to the medial flange. As observed in

319 medial view, the calcaneal socket, which accommodates the astragalar peg, is deep. Posterior

320 to it, the anterior face of the medial flange is vast and has a gently concave margin that may

321 have limited rotation of the astragalar peg. The anterior ball is convex in its anterior and

322 dorsal parts, and flat in its plantar margin as in extant crocodylians. From a lateral view, the

323 anterior ball shows a vertical wall. Ventrally, it is well demarcated from the posterior tuber by 
a deep lateroventral channel. The posterior tuber shows on its posterior margin a shallow and rugose groove.

Radiale.- The right radiale is preserved but misses most of its proximal portion (Figs. 8.1,

8.2) and is heavily eroded on its posterior surface. A portion of the facet for the ulnare is preserved on the lateral margin and distinctly projects laterally from the proximal portion of the bone. The shaft is wasp-waisted. The distal articular surface is concave.

Metacarpals.-Three metacarpals are preserved. The right metacarpal I (Figs. 8.3-8.6) is 35 $\mathrm{mm}$ long and possesses a straight shaft with proximal and distal portions being nearly as wide and in line with each other. On the proximoventral edge of the bone, a large and wider than long depression is observed on a lateral projection lateral (Figs. 8.3, 8.5) to the main shaft. The proximal articular surface is marked by a distinct dorsoventral sulcus (Fig. 8.3). The distal surface bears two condyles, each possessing deep pits on their medial and lateral surfaces. The right (Figs. 8.7, 8.10) and left metacarpals II or III are preserved. Each bone is $41 \mathrm{~mm}$ long with a rod-like shaft and a flared and convex proximal margin. In dorsal view,

340 the proximal epiphysis is rugose and projects briefly along the lateral half of the shaft (rp in 341 Fig. 8.8). Immediately medial to it, an extensive flat facet is inclined toward the medial 342 margin (Fig. 8.8). In palmar view (Fig. 8.9), a wide shallow depression is delimited by a

343 proximomedial bony ridge. The shaft has a rotated axis with the distal condyles

344 approximately $90^{\circ}$ from the proximal portion (Fig. 8.10), as observed in Congosaurus and 345 Hyposaurus (Schwarz et al. 2006). The distal condyles are well individualized and possess marked pits on their medial and lateral edges. The right or left metacarpal V (Fig. 8.11) is

347 partly weathered at both extremities, has a rod-like shaft and is $38 \mathrm{~mm}$ long. 
Phalanx.-A single carpal phalanx is preserved (Figs. 8.12-8.15). It is $18 \mathrm{~mm}$ long, wasp-

350 waisted with a proximal portion nearly as wide as the distal portion. In palmar view, the distal condyles are well demarcated by a marked intercondylar groove.

Osteoderms.- -Several osteoderms are associated with the skeleton (Figs. 3, 9). They are all displaced and therefore no clear configuration of the dorsal or ventral shield can be deduced. All dorsal osteoderms lack an external keel (Figs. 3, 9.1, 9.2) a condition identical to that of various hyposaurine dyrosaurids (Schwarz et al. 2006). The dorsal osteoderms attributed to the paravertebral shield are square to trapezoidal in outline being slightly wider than long. Their anterior and posterior margins are slightly vaulted and thin in comparison to the thick median body. As observed in dorsal view, the anterior margin is concave in its median portion 360 and its dorsal surface shows a smooth facet covering the entire width of the osteoderm. A short anterolateral process emerges from this smooth facet. Just posterior to the anterior facet, a row of nearly circular and well-aligned cupules is present. This row is distinct from the rest of the dorsal surface, which is slightly raised and ornamented with slightly larger and randomly distributed cupules. The posterior margin is gently convex. The median and lateral margins are nearly straight. As for the lateral margin, some incipient indentations are sometime visible and may have contacted a more lateral osteoderm. The ventral surface is perfectly smooth and sometime exhibits a few foramina. Isolated ventral osteoderms were also identified and present a wide V-shaped margin

369 and a peg on the opposite margin (Fig. 9.3). Part of the ventral shield is still articulated but 370 sediment hides much of the organization. A suite of four articulated osteoderms is visible on 371 one side of the specimen and is positioned ventral to the gastralia (Figs. 9.4, 9.5). Ventral 372 osteoderms are smaller than dorsal osteoderms and are distinctly wider than long. Their 373 margins possess interdigitations for suturing to other osteoderms. The medial margin is 
strongly concave whereas the lateral margin possesses a pointed process that strongly projects laterally (Fig. 9.3). The external surface is ornamented with a few barely visible shallow circular pits, which do not spread near the margins of the osteoderm. Those ventral osteoderms are gently vaulted, being nearly flat.

Ribs, gastralia and other structures.-Several elongated elements are preserved in the main block and are intertwined with the locally disarticulated skeletal parts. Their encasing in the sediment and the hiding of articular portions render their identification tentative. Thin, straight rod-like structures with a perfectly circular cross section spread to the left of the thoracic region from the eleventh to thirteenth thoracal vertebrae (Fig. 3). They are less than 5 $\mathrm{mm}$ in diameter. Thicker elements, about $10 \mathrm{~mm}$ in diameter, correspond to ribs that are also scattered in this area and offer sigmoid outlines. Another type of morphology is represented by two nearly complete structures observed in this same area (Fig. 3) as well as by some fragments recovered during acid preparation (Fig. 10). These are wide, flat on one side, convex on the other, and gently curved rib-like structures with an articular facet on one end. Remarkably, they display numerous ovoid pits on both sides that range in diameter from 1 to $3 \mathrm{~mm}$. These pits are similar to those observed on the external surface of osteoderms.

Gastroliths.-At least five pebbles (1 to $3 \mathrm{~cm}$ large) are scattered adjacent to the thirteenth thoracal vertebra (Fig. 3). Another one is observed near the eleventh vertebra. Another one was freed from the block. The nature of these stones is pure quartz and therefore different to the embedding carbonate matrix. The pebbles are not perfectly rounded and possess smooth angular edges. 
400 Taxonomic identification and comparison.-The material was initially identified as a suite of

401 vertebrae and limb bones belonging to the genus Dyrosaurus in Arambourg and Joleaud

402 (1943). The unprepared block permitted observations of weathered bone surface only (Fig. 3),

403 and although no details are given in Arambourg and Joleaud (1943), some osteoderms were

404 obviously identifiable. Since Thevenin (1911a,b), dyrosaurids were recognized as part of the

405 Crocodylia with ample descriptions available, for example Hyposaurus (Troxell, 1925) or

406 Congosaurus (Swinton, 1950). As noted by Brochu et al. (2002), dyrosaurid taxonomy has

407 been largely established on characters of the rostrum and lower jaw. Most recently erected

408 dyrosaurid species have also been established on the basis of complete skulls (Barbosa et al.

409 2008; Hastings et al. 2010; 2011; 2015). Isolated skull remains or partially articulated

410 postcranial elements are difficult to assign to a given genus or species, despite extensive

411 description of the postcranial anatomy for Hyposaurinae (e.g. Schwarz et al. 2006). Although

412 the presently described skeleton from Senegal, MHNT.PAL.2012.0.45, lacks those diagnostic

413 characters established on cranial morphology, it is assigned to the Dyrosauridae on the basis

414 of the following postcranial characters in association: (1) amphiplatyan vertebral centra; (2)

415 femoral head being twisted along the shaft by about $30^{\circ}$ from the distal condyles; (3) femur

416 with strong beak-like projection of the proximal head (Troxell, 1925); (4) strong posterior

417 cleft on the proximal surface of the tibia; (5) ischium with forward-projecting anterior iliac

418 process; (6) elongated anterior ball and narrow posterior tuber of the calcaneum; (7) absence

419 of external keel on dorsal osteoderms; (8) presence of ventral osteoderms being twice as wide

420 as long. A last character, (9) deeply pitted rib-like structures, may not be used in the diagnosis

421 of Dyrosauridae, but is discussed herein due to a single previous report in a dyrosaurid

422 specimen. These characters are detailed below and anatomical comparisons are made with

423 Alligator mississippiensis, which represents an extant eusuchian. 
Amphiplatyan vertebrae widely occur in non-eusuchian crocodylomorphs. In the post-

425 Cretaceous fossil record, only two groups of crocodylomorphs possess such a type of

426

427

428

429

vertebrae: Sebecosuchia represented by taxa living exclusively in the continental

environment, and Dyrosauridae sharing the marine habitat with longirostrine eusuchians, for which vertebral centra cannot be confounded due to their procoelous intervertebral articulation.

The femur from Poponguine is identical to that of any dyrosaurid in possessing a beak-like projecting head. As such, a right femur with a "strong beak-like curve of the head and the weak fourth trochanter" was described in Hyposaurus (Troxell, 1925). The right femur of Congosaurus bequaerti was described by Jouve and Schwarz (2004) and by Schwarz et al. (2006). A flattened femur is known for Acherontisuchus guajiraensis, for which "the fourth trochanter is large for the family and the paratrochanteric fossa is deeper than the shallow pit seen in C. bequaerti" (Hastings et al. 2011). Sena et al. (2017) described the proximal portion of a right femur for Guarinisuchus munizi. A right dyrosaurid femur was described by Arambourg (1952), who noticed that the proximal head is in line with the distal condyles (Arambourg, 1952, fig. 62), a condition also identified in the specimen from Poponguine (measuring about $30^{\circ}$ ). On the other hand, the proximal head is arranged perpendicular to the distal condyles in Congosaurus bequaerti and modern crocodylians (Arambourg, 1952; Schwarz et al. 2006 report $140^{\circ}$ in Congosaurus bequaerti). According to previous works, the morphology of the femur is variable within the family and the specimen from Poponguine most resembles Hyposaurus in sharing with it a weakly developed fourth trochanter and with the dyrosaurid femur described by Arambourg (1952) in sharing with it a femoral head in line with the distal condyles.

The tibia of dyrosaurids is distinctive in possessing a marked posterior cleft as well as a strong embayment underlining the cnemial crest, both features being well expressed at the 
proximal extremity of the bone. Although these features are present in Alligator too, they are 450 not as marked. Overall, the tibia of MHNT.PAL.2012.0.45 is similar to other tibia described 451 for dyrosaurids (Langston, 1995; Schwarz et al. 2006; Sena et al., 2017). The acetabular foramen is completely enclosed by both the ischium and the ilium, which contribute to two-third and one third of it, respectively. No clear difference is noticeable between the Senegalese ilium and that of extant eusuchians. The ischium of MHNT.PAL.2012.0.45 is comparable to other dyrosaurid ischia as described for Hyposaurus (Troxell, 1925, fig. 13), for an indeterminate Pakistanese dyrosaurid (Storrs, 1986), for Dyrosaurus sp. (Schwarz et al. 2006), for Dyrosaurus maghribensis (Jouve et al. 2006) and for Acherontisuchus guajiraensis (Hastings et al. 2011), which all display a strongly projecting anterior ischium process, an overhanging projection of the ischium process that 460 holds the dorsoventrally elongate facet for the pubis, a narrow to blade-like shaft with nearly parallel edges and a distal process that does not particularly widen distally. These characters are also visible in some notosuchians such as Yacarerani boliviensis (Leardi et al., 2015, fig. 13) or Stratiotosuchus maxhechti (Riff and Kellner, 2011, fig. 12). This is contrary to the 464 situation observed in thalattosuchians (e.g. Herrera et al. 2013, fig. 5), in extant eusuchians 465 (e.g. Mook, 1921, fig. 17) or in coelognathosuchians such as the pholidosaurids Terminonaris 466 robusta (Fig.7 in Wu et al. 2001), Oceanosuchus boecensis (Hua et al. 2007, fig. 4) or the goniopholidid Anteophthalmosuchus (Martin et al. 2016, fig. 15). The shaft in the continuity of the ischiac blade of MHNT.PAL.2012.0.45 is wide but not as wide as that of Dyrosaurus sp. (Schwarz et al. 2006) and the overhanging anterior ischiac process is not as much constricted against the shaft as that seen in Dyrosaurus sp. (compare with Schwarz et al. 2006, fig. 10C). The only other described calcaneum for a dyrosaurid belongs to Rhabdognathus sp. 473 from the Paleocene of Saudi Arabia (Storrs, 1995), which is preserved in connection with an 
astragalus and is similar in its proportions to MHNT.PAL.2012.0.45. The calcaneum of MHNT.PAL.2012.0.45 differs from that of the extant Alligator in possessing a longer than wide anterior ball and a taller than wide posterior tuber. The calcaneum of Alligator possesses a lateral projection arising from the lateral surface of the posterior tuber; in the dyrosaurid MHNT.PAL.2012.0.45, this process is absent. All other characters described in MHNT.PAL.2012.0.45 are similar to that of Alligator.

The dermal armor of dyrosaurids is composed of both a dorsal and a ventral shield (e.g. Schwarz et al. 2006), and the specimen from Poponguine preserves disarticulated dorsal elements as well as some ventral elements in articulation (Fig. 9). The dorsal elements of MHNT.PAL.2012.0.45 are quadrangular and lack a median keel, a condition seemingly unique to Dyrosauridae (Schwarz et al. 2006; Martin, 2015). Among Dyrosauridae, the osteoderms of Anthracosuchus balrogus are different from those described here or from any other dyrosaurids in being thick, unpitted and devoid of an imbricating surface (Hastings et al., 2015). Thick osteoderms have also been described in Congosaurus bequaerti (Jouve and Schwarz, 2004; Schwarz et al., 2006) but these are not as thick as in A. balrogus. The dorsal osteoderms of the median series in D. maghribiensis exhibit a laterally projecting peg on their anterolateral margin (Jouve et al., 2006). None of these characters are seen in the Poponguine specimen, which osteoderms morphology is typical of hyposaurine taxa (Schwarz et al., 2006). As stated previously and contrary to Dyrosauridae, the osteoderms of Goniopholididae and Pholidosauridae share a wider than long morphology and the possession of an anterolateral keel (Martin, 2015). In MHNT.PAL.2012.0.45, a series of four elements of the ventral shield are preserved in articulation (Figs. 9.4, 9.5). These wider than long elements are not comparable to the hexagonal ventral elements described in goniopholidids (Martin et al. 2016) or in the pholidosaurid Terminonaris robusta (Wu et al. 2001). 
Massive, flat and deeply pitted rib-like structures are present in the Poponguine specimen (Fig. 10). Similar bony structures were briefly described and figured for Rhabdognathus sp. by Langston (1995) and identified as costal cartilages. At present, these elements cannot be identified with certainty. Their morphology is intriguing and attention should be kept in the future on such elements, whether they could be pathological or more widespread among dyrosaurids.

The present description of dyrosaurid postcranial elements, although not permitting an identification beyond Dyrosauridae indet., brings some additional knowledge on the morphology of this particular group with details often obscured by compression or articulation when relatively complete specimens are available. A close relationship between dyrosaurids and outgroup taxa such as the Pholidosauridae, Thalattosuchia or Gavialoidea has often been proposed in phylogenetic works and problems related to branch attraction in phylogenies have been discussed (Pol and Gasparini, 2009; Martin et al. 2016). Updating phylogenetic codings with new morphological details as those presented here, may help tease apart such problems. For example, the morphology of osteoderms, both dorsal and ventral, differs between these groups of longirostrine forms. Current efforts of describing the 514 postcranial anatomy of various crocodylomorph lineages (e.g. Pol et al. 2011; Herrera et al. 2013; Leardi et al. 2015; Martin et al. 2016) will, among other phylogenetic problems, permit to identify what characters are independent of longirostry.

518 Presence of gastroliths. - The presence and significance of gastroliths or stomach stones in 519 marine reptiles (Taylor, 1993) and more generally among vertebrates (Wings, 2007) has been 520 discussed at length. Denton et al. (1997) interpreted the presence of gastroliths in the stomachal area of the dyrosaurid Hyposaurus to serve as ballasts, both for diving or to prevent rolling in the waves. Our observations on the Senegalese specimen does not support this view 
because despite their sizeable dimensions, the total mass of the gastroliths is estimated at

524 about 100 grams and is insufficient to account for a role as ballast in comparison to the total weight of the animal. Indeed, the animal total weight cannot be precisely reconstructed here but may have certainly surpassed $50 \mathrm{~kg}$, which is a highly imprecise estimation. It is

527 nevertheless highly unlikely that $0.2 \%$ of this weight would have a ballast effect.

528 Furthermore, previous studies including crocodiles fed experimentally with stones and experimental models revealed that gastrolith masses accounting for less than $2 \%$ of body mass do not play a role in buoyancy or stability because the studied crocodiles compensate for

531 added weight by augmenting lung volume (Kirshner, 1985; Henderson, 2003; Grigg and

532 Kirshner, 2015).

One hypothesis that requires further attention invokes an improvement of dive time thanks to gastrolith weight due to the indirect consequence of increasing lung volume

535 (Seymour, 1982 and discussion in Gregg and Kirshner 2015). Observations on extant crocodiles have shown that pebbles are deliberately swallowed with some animals going into

537 specific areas to collect gastroliths (Cott, 1961). The gastroliths preserved in the stomachal 538 cavity of MHNT.PAL.2012.0.45 are clearly allochthonous, the depositional environment

539 where the specimen was recovered consisting exclusively of fine-grained limestone.

540 Dyrosaurids had enhanced capacities for swimming (Schwarz et al. 2006) and may have

541 travelled long oceanic distances. Therefore, the origin of the gastroliths is unknown and their 542 precise function, if any, remain unknown.

544 Fossil record of Danian dyrosaurids.-The Senegalese dyrosaurid described in the present 545 work adds to the limited record of Danian dyrosaurids from Africa. Originally presented as 546 Montian (an equivalent to the Selandian) by Buffetaut (1979), the taxon Atlantosuchus 547 coupatezi from Sidi Chenane in the Oulad Abdoun Basin of Morocco has been attributed a 
548 Danian age based on the selachian assemblage recovered in the sedimentary matrix (Jouve et

549 al. 2008). Atlantosuchus coupatezi is known from a mandibular symphysis (Buffetaut, 1979)

550 and from skull elements including a nearly complete skull as well as some cervical vertebrae

551 (Jouve et al. 2008). There is no anatomical overlap with the material from Poponguine so no

552 comparison can be made. Another African dyrosaurid of possible Danian age is

553 Phosphatosaurus sp. reported on the basis of a portion of symphysis from Gadamata in the

554 Adar Doutchi of Niger as well as from fragmentary remains collected by René Lavocat in

555 Mali (Buffetaut, 1978a). Again, no anatomical overlap exists with the Senegalese specimen.

556 At about the same latitude as Senegal, dyrosaurids are also known from Danian

557 deposits in Brazil (Cope, 1886) and from the early Paleocene of Bolivia (Buffetaut, 1991).

558 Given the proximity of coastlines during the Eocene of the recently opened North Atlantic

559 Ocean, faunal exchanges between these two provinces may have been easily covered by

560 marine dwelling organisms such as dyrosaurids. Reports from the Danian of Brazil including

561 Hyposaurus derbianus (Cope, 1886) concerned fragmentary specimens from the Maria

562 Farinha Formation (see review in Hastings et al. 2010). Guarinisuchus munizi is known from

563 a complete skull and few postcranial elements, also from the Maria Farinha Formation of

564 Brazil (Barbosa et al. 2008) and recently, other mandibular and cranial remains have been

565 assigned to this species (Sena et al. 2017).

566 Finally, Danian material from Alabama, USA has been revised and assigned to

567 Hyposaurus rogersii by Denton et al. (1997). The material includes various vertebrae,

568 osteoderms, an ischium, part of a femur and other postcranial fragments (see list in Denton et

569 al. 1997). Although anatomical overlap with the Poponguine material exists, the Alabama

570 specimens have not been described in detail. Moreover, their attribution to Hyposaurus

571 rogersii needs to be re-evaluated by emending the diagnosis of the species with postcranial 
material. Presently, the most diagnostic specimen of the species comprises one complete skull from the Maastrichtian of New Jersey (Buffetaut, 1976; Denton et al. 1997).

A revision of $H$. rogersii is potentially important to better understand dyrosaurid survival across the $\mathrm{K} / \mathrm{Pg}$ boundary. As presently understood, four species of dyrosaurids (perhaps five if Phosphatosaurus is included) are known from Danian deposits worldwide and include Atlantosuchus coupatezi, Guarinisuchus munizi, Hyposaurus derbianus and Hyposaurus rogersii. Previous studies have merged post-K/Pg dyrosaurid diversity (i.e. Danian, Selandian, Thanetian) in a whole Paleocene time bin (e.g. Jouve et al. 2008), which may overestimate diversity counts and not reflect the effects of the $\mathrm{K} / \mathrm{Pg}$ mass extinction on dyrosaurid survival directly after the event. Therefore, focusing on the Danian diversity through collecting efforts will certainly improve this aspect. Jouve et al. (2008) and Barbosa et al. (2008) concurred with the idea that dyrosaurids may have been under competition with the diverse mosasaurs of the Maastrichtian. Whether the extinction of mosasaurs at the K/Pg boundary freed some ecological space for dyrosaurids during the Paleocene is possible but still untested (Martin et al. 2017). It is equally possible that dyrosaurid diversity only started to increase later in the Paleocene but admittedly, the dating constraints on the Paleocene dyrosaurid record remains imprecise, despite the availability of some stratigraphic studies, notably from Mali (Hill et al. 2008).

\section{Conclusions}

Although the early Paleocene marine deposits of Senegal are less fossiliferous with respect to vertebrate remains than other terrains in northern Africa such as the phosphate deposits of Morocco, they are potentially important for the fossil record of the Dyrosauridae and other marine reptiles that survived the end Cretaceous mass extinction events. The present 
description of a partial dyrosaurid skeleton from Danian deposits adds to the limited record of dyrosaurids of that age worldwide. Thanks to its state of preservation, the specimen also provides an update on the postcranial morphology of the Dyrosauridae and therefore adds new insights into potential characters to consider in future phylogenies.

\section{Acknowledgments}

Several persons provided insights and information that helped us retrace part of the lost history of the specimen described in this work. We express our sincere thanks to Y. Laurent and F. Duranthon (MHNT, Toulouse), E. Buffetaut (ENS Paris), J. Claude (ISEM, Montpellier), E. Robert and S. Passot (Univ. Lyon) and S. Charbonnier (MNHN, Paris). The specimen was prepared by S. Unal and S. Jiquel (ISEM, Montpellier). We thank S. Jouve, A. Hastings and E. Frey for their time and effort in reviewing a previous version of this work.

\section{References}

Arambourg, C., 1952, Les vertébrés fossiles des gisements de phosphates (Maroc, Algérie, Tunisie): Notes et mémoires du service géologique du Maroc, v. 92, p. 1-396.

Arambourg, C., and Joleaud, L., 1943, Vertébrés fossiles du bassin du Niger: Bulletin de la direction des mines, Dakar, Grande Imprimerie Africaine, v. 7, p. 30-76.

Barbosa, J.A., Kellner, A.W.A., and Viana, M.S.S., 2008, New dyrosaurid crocodylomorph and evidences for faunal turnover at the K-P transition in Brazil: Proceedings of the Royal Society of London B: Biological Sciences, v. 275, p. 1385-1391.

Bergounioux, F-M., 1952, Appendice: Chéloniens fossiles des phosphates de Gafsa, in Arambourg, C., ed., Les vertébrés fossiles des gisements de phosphates (Maroc, 

396.

624 Bergounioux, F-M., 1956, Les reptiles fossiles des dépôts phosphatés sud tunisiens: Annales des mines et de la géologie, v. 15, p. 1-105.

626 Brochu, C.A., Mamadou, L.B., Sissoko, F., Roberts, E.M., and O'Leary., M.A., 2002, A dyrosaurid crocodyliform braincase from Mali: Journal of Paleontology, v. 76, p. 10601071.

629 Buffetaut, E., 1976, Une nouvelle définition de la famille des Dyrosauridae de Stefano, 1903 (Crocodylia, Mesosuchia) et ses conséquences: inclusion des genres Hyposaurus et Sokotosuchus dans les Dyrosauridae: Geobios, v. 9, p. 333-336.

632 Buffetaut, E., 1977, Données nouvelles sur les crocodiliens paléogènes du Pakistan et de Birmanie: Comptes Rendus de l'Académie des Sciences, Paris, série D, v. 285, p. 869872.

635 Buffetaut, E., 1978a, Les Dyrosauridae (Crocodylia, Mesosuchia) des phosphates de l'Eocène inférieur de Tunisie : Dyrosaurus, Rhabdognathus, Phosphatosaurus: Géologie Méditerranéenne, v. 5, p. 237-256. Geologie und Paläontologie Abhandlungen, v. 156, p. 262-283.

640 Buffetaut, E., 1979, Atlantosuchus coupatezi, n. g., n. sp., un nouveau Dyrosauridé (Crocodylia, Mesosuchia) des phosphates Montiens du Maroc: Bulletin Trimestriel de

644 Buffetaut, E., 1980, Les crocodiliens paléogènes du Tilemsi (Mali) : un aperçu systématique. Palaeovertebrata, v. Mémoire Jubilaire en l'honneur de René Lavocat, p. 15-35. 
646 Buffetaut, E., 1982, Radiation évolutive, paléoécologie et biogéographie des crocodiliens mésosuchiens: Société géologique de France, v. 142 , p. 1-85.

648 Buffetaut, E., 1991, Fossil crocodilians from Tiupampa (Santa Lucia Formation, Early Paleocene), Bolivia : a preliminary report: Revista Técnica de Yacimientos Petroliferos Fiscales Bolivianos, Fosiles y Facies da Bolivia, I, Vertebrados, v. 12, p. 541-544.

651 Buffetaut, E., and Lauverjat, J., 1978, Un crocodilien d'un type particulier dans le Cénomanien 652 de Nazaré: Comptes Rendus Sommaires de la Société Géologique de France, v. 2, p. $79-82$.

654 Castelain J., Jardiné, S., and Monciardini, C., 1965, Excursions géologiques dans le Sénégal occidental - Colloque International de Micropaléontologie (Dakar): Mémoire du Bureau

657 658 659 660 de Recherches Géologiques et Minières, v. 32, p. 357-365.

Churcher C.S., and Russell, D.A., 1992, Terrestrial vertebrates from Campanian strata in Wadi El-Gedid (Kharga and Dahkleh Oases), Western Desert of Egypt: Journal of Vertebrate Paleontology, v. 12, p. 23A.

Cope, E.D., 1886, A contribution to the vertebrate paleontology of Brazil: Proceedings of the American Philosophical Society, v. 23, p. 1-20.

Cott, H.B., 1961, Scientific results of an inquiry into the ecology and economic status of the Nile Crocodile (Crocodilus niloticus) in Uganda and Northern Rhodesia: The Transactions of the Zoological Society of London, v. 29, p. 211-356.

Denton, R.K., Dobie, J.L., and Parris, D.C., 1997, The marine crocodilian Hyposaurus in North America, in Callaway, J.M., and Nicholls, E.L., eds., Ancient Marine Reptiles: Academic Press, p. 375-397.

De Stefano, G., 1903, Nuovi rettili degli strati a fosfato della Tunisia: Bollettino delle Società Geologica Italiana, v. 22, p. 51-80. 
670 Faye, A, 1983, Contribution à l'étude géologique et hydrogéologique du horst de Ndiass (Sénégal occidental): Thèse doctorat $3^{\text {ème }}$ cycle, Université de Dakar, $160 \mathrm{p}$.

672 Grigg, G., and Kirshner, D., 2015, Biology and evolution of crocodylians: CSIRO Publishing, Australia, $627 \mathrm{p}$.

674 Hastings, A.K., Bloch, J.I., Cadena, E.A., and Jaramillo, C.A., 2010, A new small shortsnouted dyrosaurid (Crocodylomorpha, Mesoeucrocodylia) from the Paleocene of Northeastern Colombia: Journal of Vertebrate Paleontology, v. 30, p. 139-162.

677 Hastings, A.K., Bloch, J.I., and Jaramillo, C.A., 2011, A new longirostrine dyrosaurid (Crocodylomorpha, Mesoeucrocodylia) from the Paleocene of north-eastern Colombia: biogeographic and behavioural implications for New-World Dyrosauridae: Palaeontology, v. 54, p. 1095-1116. the Palaeocene of Colombia: Historical Biology, v. 27, p. 998-1020.

684 Hay, O.P., 1930, Second Bibliography and Catalogue of the Fossil Vertebrata of North America: Carnegie Institute Washington, Washington DC, v. 2, 1094 p..

686 Henderson, D.M., 2003, Effects of stomach stones on the buoyancy and equilibrium of a floating crocodilian: a computational analysis: Canadian Journal of Zoology, v. 81, p.

689 Herrera, Y., Fernández, M.S., and Gasparini, Z., 2013, Postcranial skeleton of Cricosaurus araucanensis (Crocodyliformes: Thalattosuchia): morphology and palaeobiological insights: Alcheringa, v. 37, p. 285-298.

692 Hill, R.V., Mccartney, J.A., Roberts, E., Bouaré, M., Sissoko, F., and O'leary, M.A., 2008, Dyrosaurid (Crocodyliformes: Mesoeucrocodylia) fossils from the Upper Cretaceous 
and Paleogene of Mali: implications for phylogeny and survivorship across the K/T Boundary: American Museum Novitates, v. 3631, p. 1-19. Rendus Hebdomadaires des Séances de l'Académie des Sciences, v. 202, p. 335-337.

698 (Mesoeucrocodylia : Dyrosauridae) from the Lower Eocene of North Africa: Canadian Journal of Earth Sciences, v. 42, p. 232-337.

Jouve, S., 2007, Taxonomic revision of the dyrosaurid assemblage (Crocodyliformes : Mesoeucrocodylia) from the Paleocene of the Iullemmeden Basin, West Africa: Journal of Paleontology, v. 81, p. 163-175.

Jouve, S., and Schwarz, D., 2004, Congosaurus bequaerti, a Paleocene dyrosaurid (Crocodyliformes ; Mesoeucrocodylia) from Landana (Angola): Bulletin de l'Institut Royal des Sciences Naturelles de Belgique, sciences de la terre, v. 74, p. 129-146.

Jouve, S., Bouya, B., and Amaghzaz, M., 2008, A long-snouted dyrosaurid (Crocodyliformes, Mesoeucrocodylia) from the Palaeocene of Morocco: phylogenetic and palaeobiogeographic implications: Palaeontology, v. 51, p. 281-294.

Kear, B.P., Rich, T.H., Ali, M.A., Al-Mufarrih, Y.A., Matiri, A.H., Masary, A.M., and Attia, Y., 2008, Late Cretaceous (Campanian-Maastrichtian) marine reptiles from the Adaffa Formation, NW Saudi Arabia: Geological Magazine, v. 145, p. 648-654.

Kirshner, D.S., 1985, Buoyancy control in the estuarine crocodile, Crocodylus porosus Schneider. PhD thesis, The University of Sydney, $165 \mathrm{p}$.

Lamanna, M.C., Smith, J.B., Attia, Y.S., and Dodson, P., 2004, From dinosaurs to dyrosaurids (Crocodyliformes): removal of the post-Cenomanian (Late Cretaceous) record of Ornithischia from Africa: Journal of Vertebrate Paleontology, v. 24, p. 764-768. 
Langston, W., 1995, Dyrosaurs (Crocodilia, Mesosuchia) from the Paleocene Umm Himar Formation, Kingdom of Saudi Arabia: US Geological Survey Bulletin, v. 2093, p. F1F36.

Leardi, J.M., Pol, D., Novas, F.E., and Suárez Riglos, M., 2015, The postcranial anatomy of Yacarerani boliviensis and the phylogenetic significance of the notosuchian postcranial skeleton: Journal of Vertebrate Paleontology, v. 35, e995187.

Legoux, P., 1937, Service Géologique de l’Afrique Occidentale Française. Rapport Annuel, p. $1-21$.

Malavoy, J., 1934, Service Géologique de l'Afrique Occidentale Française. Rapport Annuel, p. $1-18$.

Malavoy, J., 1935, Service Géologique de l’Afrique Occidentale Française. Rapport Annuel, p. $1-19$.

Martin, J.E., Amiot, R., Lécuyer, C., and Benton, M.J., 2014, Sea surface temperature contributes to marine crocodylomorph evolution: Nature Communications, v. 5, 4658, doi:10.1038/ncomms5658.

Martin, J.E., 2015, A sebecosuchian in a middle Eocene karst with comments on the dorsal shield in Crocodylomorpha: Acta Palaeontologica Polonica, v. 60, p. 673-680.

Martin, J.E., Delfino, M., and Smith, T., 2016, Osteology and affinities of Dollo's goniopholidid (Mesoeucrocodylia) from the Early Cretaceous of Bernissart, Belgium: Journal of Vertebrate Paleontology, v. 36, e1222534.

Martin, J.E., Raslan-Loubatié, J., and Mazin, J.-M., 2016, Cranial anatomy of Pholidosaurus purbeckensis from the Lower Cretaceous of France and its bearing on pholidosaurid affinities: Cretaceous Research, v. 66, p. 43-59. 
741 Martin, J.E., Vincent, P., Tacail, T., Khaldoune, F., Jourani, E., Bardet, N., and Balter, V.,

742

743

744

745

746

747

748

749

750

751

752

753

754

755

756

757

758

759

760

761

762

763

764 Sarr R., and Ly, A., 1998, Contribution à l'étude biostratigraphique de la falaise de Poponguine

765 2017, Calcium Isotopic Evidence for Vulnerable Marine Ecosystem Structure Prior to the K/Pg Extinction: Current Biology, v. 27, p. 1641-1644.

O’Leary, M.A., Roberts, E.M., Bouare, M., Sissoko, F., and Tapanila, L., 2006, Malian paenungulata (Mammalia : Placentalia) : new african afrotheres from the early Eocene. Journal of Vertebrate Paleontology, v. 26, p. 981-988.

Pilgrim, G.E., 1940, Middle Eocene mammals from North-West India: Proceedings of the Zoological Society of London, B, v. 110, p. 127-152.

Pol, D., and Gasparini, Z., 2009, Skull anatomy of Dakosaurus andiniensis (Thalattosuchia: Crocodylomorpha) and the phylogenetic position of Thalattosuchia: Journal of Systematic Palaeontology, v. 7, p. 163-197.

Pol, D., Leardi, J.M., Lecuona, A., and Krause, M., 2012, Postcranial anatomy of Sebecus icaeorhinus (Crocodyliformes, Sebecidae) from the Eocene of Patagonia: Journal of Vertebrate Paleontology, v. 32, p. 328-354.

Salih, K.A.O., Evans, D.C., Bussert, R., Klein, N., Nafi, M., and Müller, J., 2015, First record of Hyposaurus (Dyrosauridae, Crocodyliformes) from the Upper Shendi Formation of Sudan: Journal of Vertebrate Paleontology, v. 36, e1115408.

Sarr, R., 1995, Étude biostratigraphique et paléoenvironnementale des séries d'âge Crétacé terminal à Eocène moyen du Sénégal occidental. Systématique et migration des ostracodes: Thèse de Doctorat d'Etat ès Sciences, Université Cheikh Anta Diop de Dakar, 384 p.

Sarr, R., 1998, Les ostracodes paléocènes du horst de Diass (Sénégal): biostratigraphie, systématique, paléoenvironnements: Revue de Micropaléontologie, v. 41, p. 151-174.

(Sénégal occidental): Bulletin de l'IFAN Cheikh Anta Diop, série A, v. 49, p. 103-132. 
Schwarz, D., Frey, E., and Martin, T., 2006, The postcranial skeleton of the hyposaurinae (Dyrosauridae; Crocodyliformes): Palaeontology, v. 49, p. 695-718.

Sena, M.V.A., de Andrade, R.C.L.P., Bantim, M., Sayão, J.M., Barbosa, J.A., and de Oliveira, G. R., 2017, New dyrosaurid remains (Crocodyliformes, Mesoeucrocodylia) from the Paleocene of the Paraíba Basin, NE Brazil: Revista Brasileira de Paleontologia, v. 20, p. $345-354$.

Sertich, J., Manthi, F.K., Sampson, S., Loewen, M., and Getty, M., 2006, Rift valley dinosaurs: a new Late Cretaceous vertebrate fauna from Kenya: Journal of Vertebrate Paleontology, v. 26, p. 124A.

Seymour, R.S., 1982, Physiological adaptations to aquatic life, in Gans, C., and Pough, F.H., Eds., Biology of the Reptilia, Physiological Ecology: Academic Press v. 13.: p. 1-51.

Storrs, G., 1986, A dyrosaurid crocodile (Crocodylia : Mesosuchia) from the Paleocene of Pakistan: Postilla, v. 197, p. 1-16.

Swinton, W.E., 1950, On Congosaurus bequaerti Dollo. Annales du Musée du Congo Belge: v. 13, p. 9-56.

Taylor, M., 1993, Stomach stones for feeding or buoyancy? The occurrence and function of gastroliths in marine tetrapods: Philosophical Transactions of the Royal Society of London, B, v. 341, p. 163-175.

Tessier, F., 1952, Contribution à la stratigraphie et à la paléontologie de la partie Ouest du Sénégal (Crétacé et Tertiaire): Bulletin de la Direction des Mines de l'AOF, Dakar, v. 14 , p. $1-267$.

Thévenin, A., 1911a, Le Dyrosaurus des phosphates de Tunisie: Annales de Paléontologie, v. 7, p. $95-108$. 
801

Thévenin, A., 1911b, Sur la persistance d'un type de Reptile secondaire au début du Tertiaire: Comptes Rendus Sommaires des Séances de la Société Géologique de France, v. 12-13, p. $136-137$.

Troxell, E.F., 1925, Hyposaurus, a marine crocodilian: American Journal of Sciences, v. 9, p. $33-514$.

Wings, O., 2007, A review of gastrolith function with implications for fossil vertebrates and a revised classification: Acta Palaeontological Polonica, v. 52, p. 1-16.

Wu, X-C., Russell, A.P., and Cumbaa, S.L., 2001, Terminonaris (Archosauria: Crocodyliformes): new material from Saskatchewan, Canada, and comments on its phylogenetic relationships: Journal of Vertebrate Paleontology, v. 21, p. 492-514.

\section{FIGURE CAPTIONS}

FIGURE 1-Location of the dyrosaurid specimen presented in this work. (1) Map of Senegal indicating the locality of Poponguine; (2) the Danian succession at Poponguine where the specimen was discovered as photographed by G. Labitte in the 1920s from Tessier (1952).

FIGURE 2-Planktonic foraminifers recovered from the sediment of MHNT.PAL.2012.0.45, except in (2), which is from Toubab Dialaw. Chiloguembelina morsei (Kline, 1941) in (1) lateral view (PV4); (2) lateral view for comparison (TD90/4); (3) Apertural view (P88/34). Morozovella cf. trinidadensis (Bolli, 1957) in (4) ombilical (P88/23); (5) apertural (P88/23) and (6) spiral (P88/33) views. Planorotalites compressa (Plummer, 1926) in (7) spiral (P88/14), (8) ombilical (P88/14). Morozovella inconstans (Subbotina, 1953) in (9) spiral (P88/38) and (10) ombilical (P88/38) views. Morozovella pseudobulloides (Plummer, 1928) in (11) spiral (P88/10) and (12) spiral (P88/40) views. 
815 FIGURE 3-Main block containing the partially articulated dyrosaurid skeleton

816 MHNT.PAL.2012.0.45 from the Danian of Poponguine, Senegal, (1) before as indicated with

817 the stipple area and (2) following preparation. Abbreviations: $g=$ gastrolith; $1 \mathrm{f}=$ left femur;

818 lil=left ilium; lis=left ischium; ost=osteoderm; rf=right femur; ril=right ilium; ris=right

819 ischium; rls=rib-like structures; $\mathrm{c} 1-\mathrm{c} 4=$ caudal vertebrae; $\mathrm{s} 1-\mathrm{s} 2=$ sacral vertebrae; $\mathrm{t} 11-$

$820 \quad \mathrm{t} 15=$ thoracic vertebrae.

821

822 FigURE 4-Selected vertebrae of MHNT.PAL.2012.0.45 from the Danian of Poponguine,

823 Senegal. Thoracic vertebra \#10 in (1) anterior; (2) posterior; (3) dorsal; (4) ventral and (5) left

824 lateral views; sacral vertebra \#2 in (6) anterior; (7) posterior; (8) dorsal; (9) ventral and (10)

825 right lateral views; caudal vertebra \#1 in (11) anterior; (12) posterior; (13) dorsal; (14) ventral

826 and (15) left lateral views; caudal vertebra \#2 in (16) anterior; (17) posterior; (18) dorsal; (19)

827 ventral and (20) left lateral views; caudal vertebra \#3 in (21) right lateral view. The black

828 arrows indicate the position of haemal facets; the white arrow indicates the erosive lesion.

829

830 FigURE 5-Elements of the sacrum of MHNT.PAL.2012.0.45 from the Danian of

831 Poponguine, Senegal. Left ilium in (1) dorsal; (2) ventral; (3) lateral; (4) medial views. Left

832 ischium in (5) dorsal and (6) lateral views. Right ischium and fragmentary right ilium in

833 lateral view with (7) line drawing and (8) associated photograph; (9) posterior view.

834 Abbreviations: af=acetabular foramen; afi=anterior facet for ilium; afis=anterior facet for

835 ischium; afp=anterior facet for pubis; aip=anterior iliac process; ap=anterior process;

$836 \mathrm{fe}=$ femur; $\mathrm{ff}=$ facet for femur; $\mathrm{ib}=\mathrm{ischiac}$ blade; $\mathrm{il}=\mathrm{ilium}$; ost=osteoderm; $\mathrm{pfi}=$ posterior facet

837 for ilium; $p$ fis=posterior facet for ischium; $p i p=$ posterior iliac process; $p p=$ posterior process;

838 ps $=$ posterior scar; $\mathrm{sac}=$ supraacetabular crest; $\mathrm{s} 1=$ sacral vertebra 1. 
840 FigURE 6-The hind limb of MHNT.PAL.2012.0.45 from the Danian of Poponguine,

841 Senegal. Left femur in (1) proximal view; (2) dorsal view of the proximal third portion; (3)

842 ventral view of the proximal third portion; (4) ventral view of the distal end; (5) distal view;

843 (6) medial and (7) lateral views. Left tibia in (8) lateral; (9) proximal; (10) anterior and (11)

844 posterior views. Abbreviations: $\mathrm{cff}=$ caudofemoralis flange; $\mathrm{cn}=\mathrm{cnemial}$ crest; $\mathrm{dep}=\mathrm{depressed}$

845 zone; $\mathrm{lc}=$ lateral condyle; $\mathrm{k}=\mathrm{knob} ; \mathrm{mc}=$ medial condyle; ost $=$ osteoderm; $\mathrm{pcl}=$ posterior $\mathrm{cleft}$;

846 proc $=$ process; $4 \mathrm{t}=$ fourth trochanter.

847

848 Figure 7-The left calcaneum of MHNT.PAL.2012.0.45 from the Danian of Poponguine,

849 Senegal in (1) medial; (2) anterior; (3) lateral; (4) posterior; (5) dorsal and (6) ventral views.

850 Abbreviations: $\mathrm{ab}=$ anterior ball; $\mathrm{cs}=$ calcaneal socket; lvc=lateroventral channel; $\mathrm{mc}=$ medial 851 channel; $\mathrm{mf}=$ medial flange; $\mathrm{ptu}=$ posterior tuber.

852

853 FigURE 8-Elements of the manus of MHNT.PAL.2012.0.45 from the Danian of Poponguine,

854 Senegal. Right radiale in 1, anterior and 2, distal views. Right metacarpal I in (3) proximal;

855 (4) dorsal; (5) palmar and (6) distal views. Right metacarpal II or III in (7) proximal; (8) 856 dorsal; (9) palmar and (10) distal views. (11) Metacarpal V in lateral or medial view. Phalanx

857 in (12) proximal; (13) dorsal; (14) palmar and (15) distal views. Abbreviations: $\mathrm{mf}=$ =medial

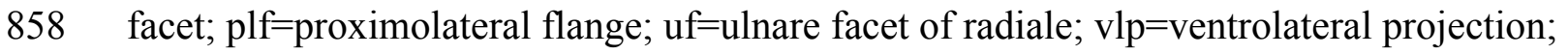

$859 \mathrm{rp}=$ rugose projection; $\mathrm{sd}=$ shallow depression. For proximal and distal views, the dorsal aspect 860 is up.

862 FigurE 9-The osteoderms of MHNT.PAL.2012.0.45 from the Danian of Poponguine,

863 Senegal. $(\mathbf{1}, \mathbf{2})$ examples of dorsal elements and of a (3) ventral element with an arrow 
864 indicating the lateral expansion. Series of four osteoderms from the ventral shield preserving

865 their original organization in (4) ventral and (5) lateral views.

866

867 FigurE 10—Rib-like element of MHNT.PAL.2012.0.45 from the Danian of Poponguine,

868 Senegal presenting numerous ovoid pits on its surface. Abbreviation: af=articular facet. 


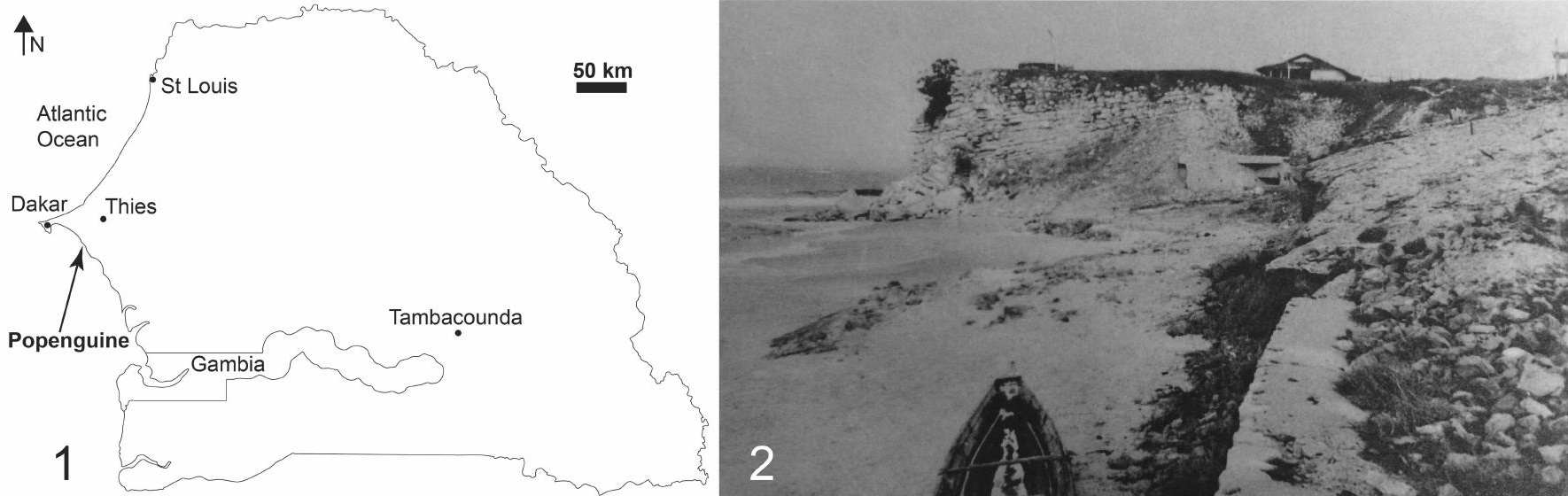




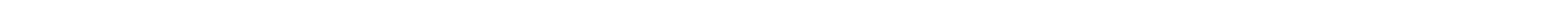



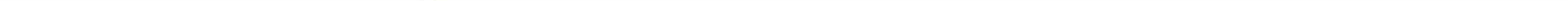


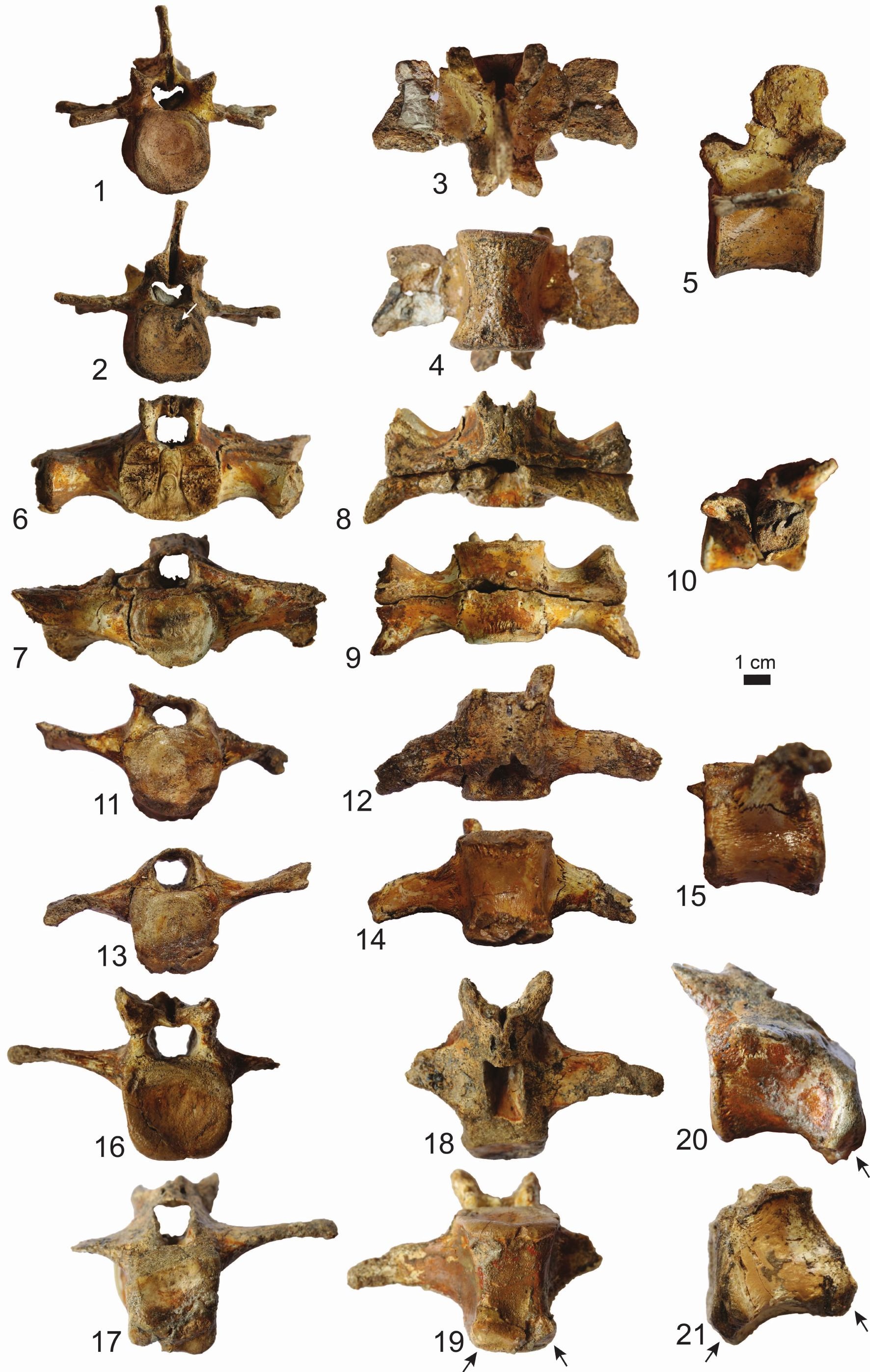




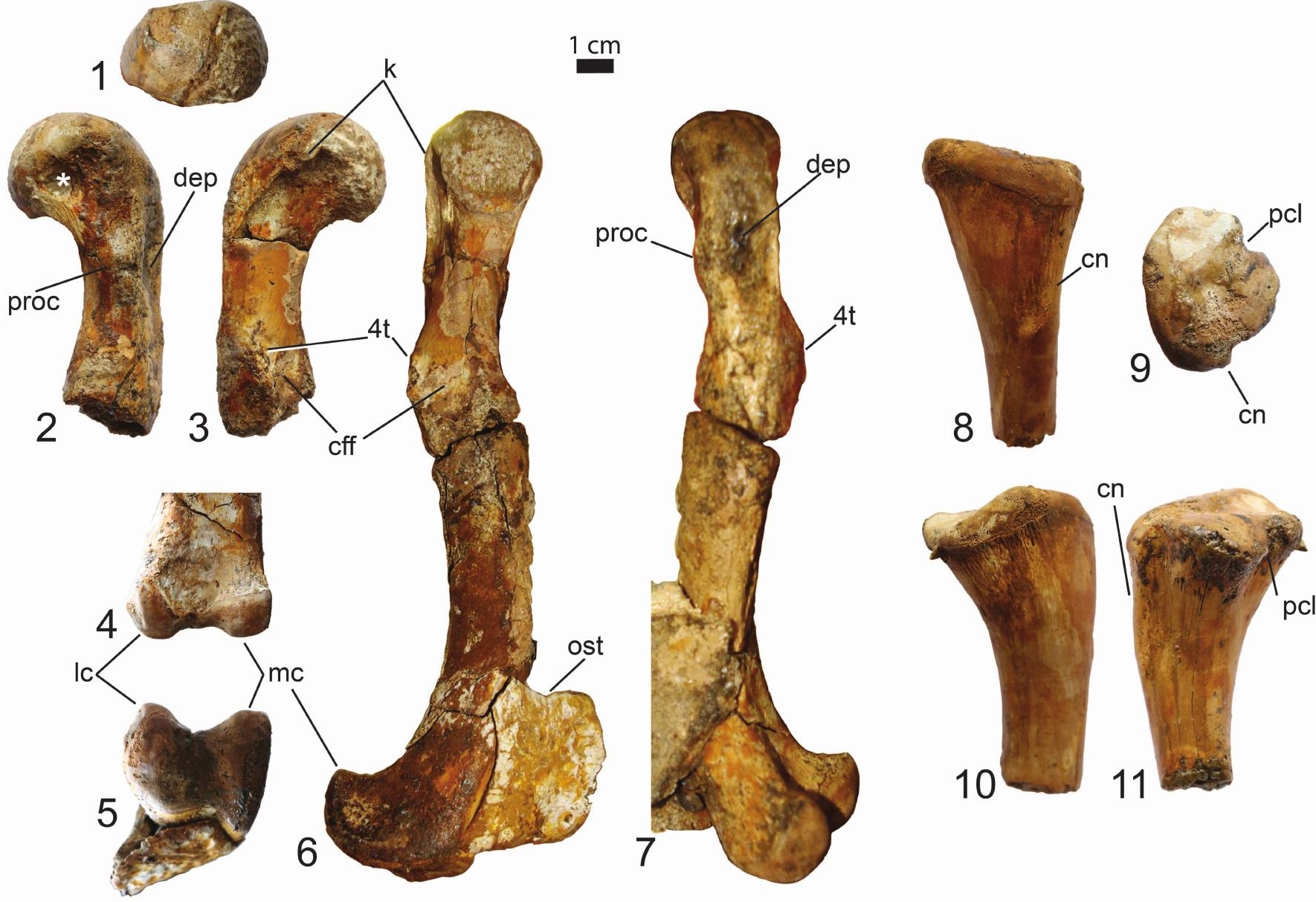




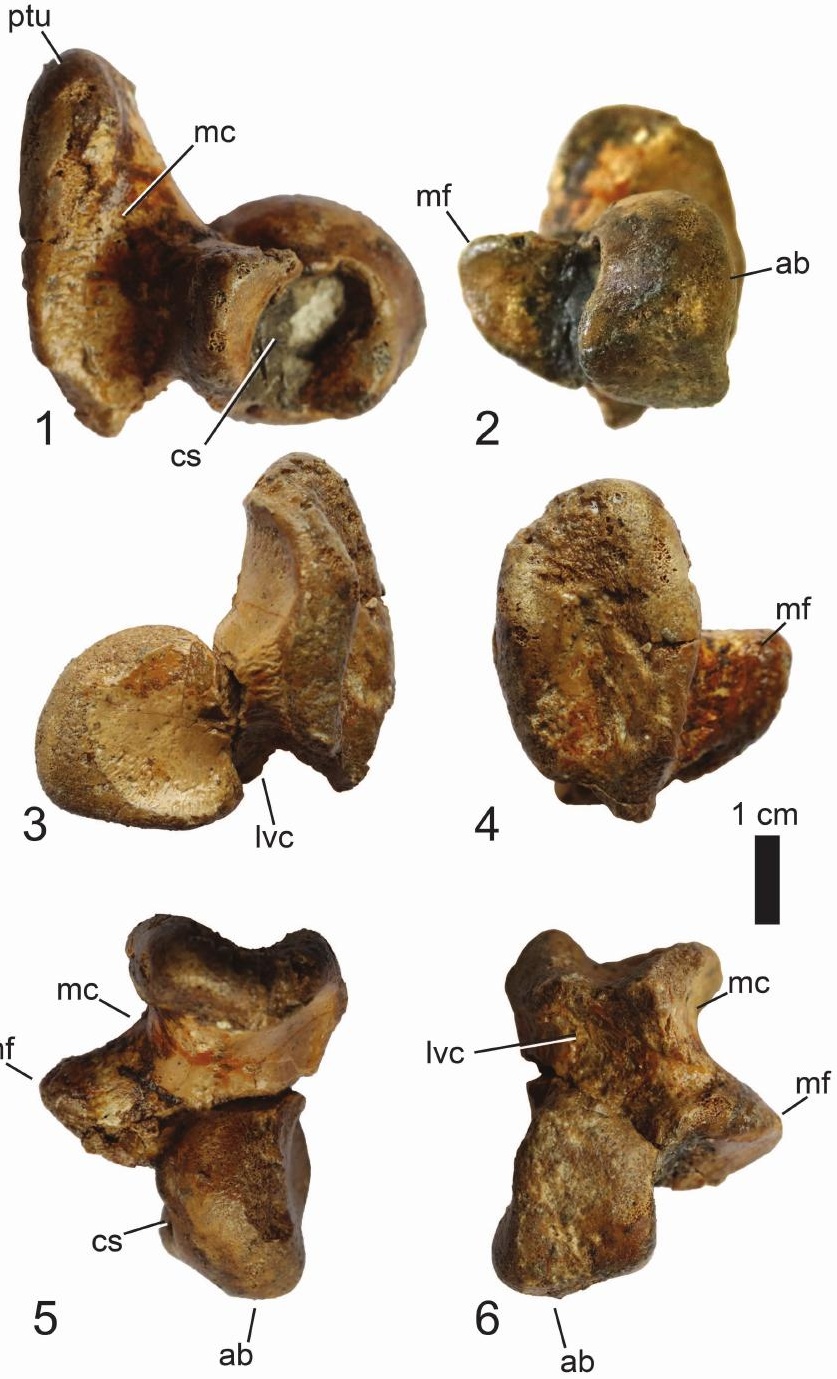




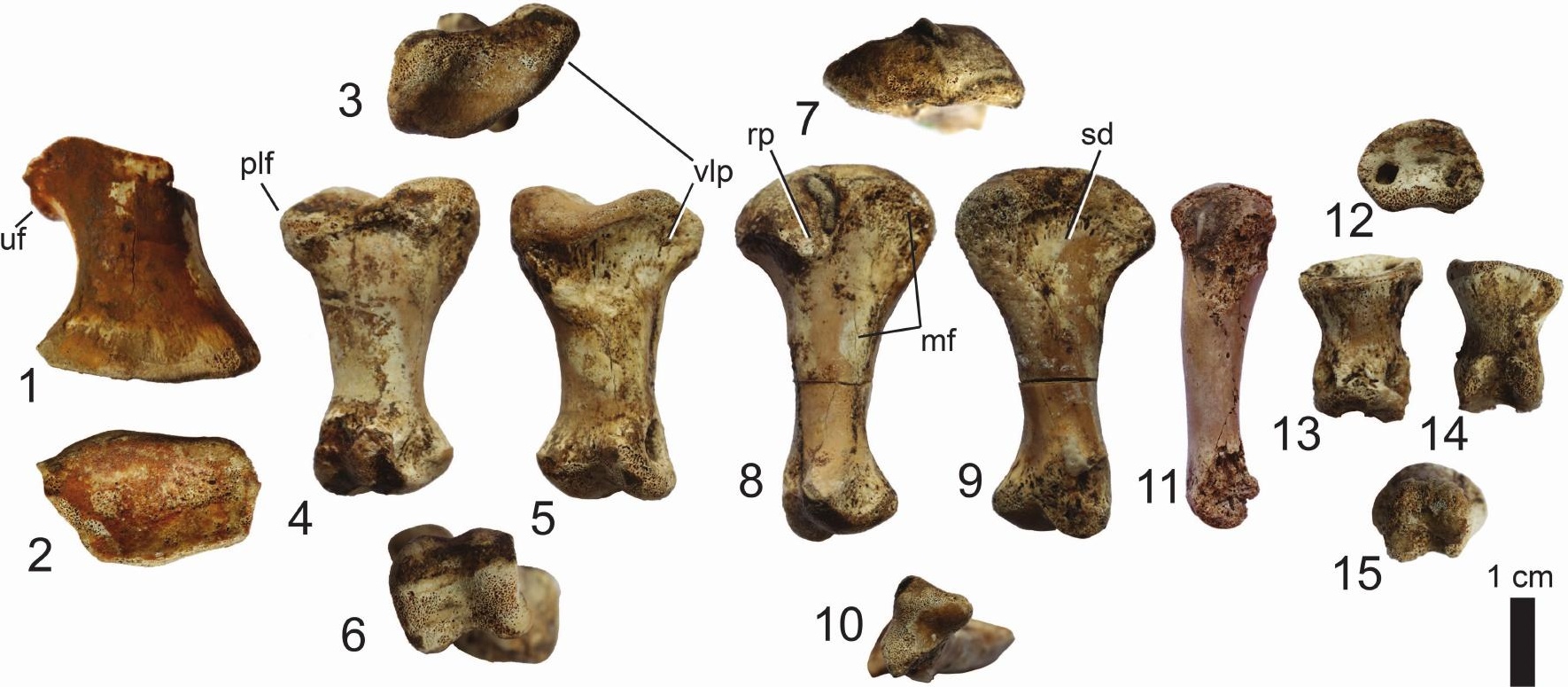



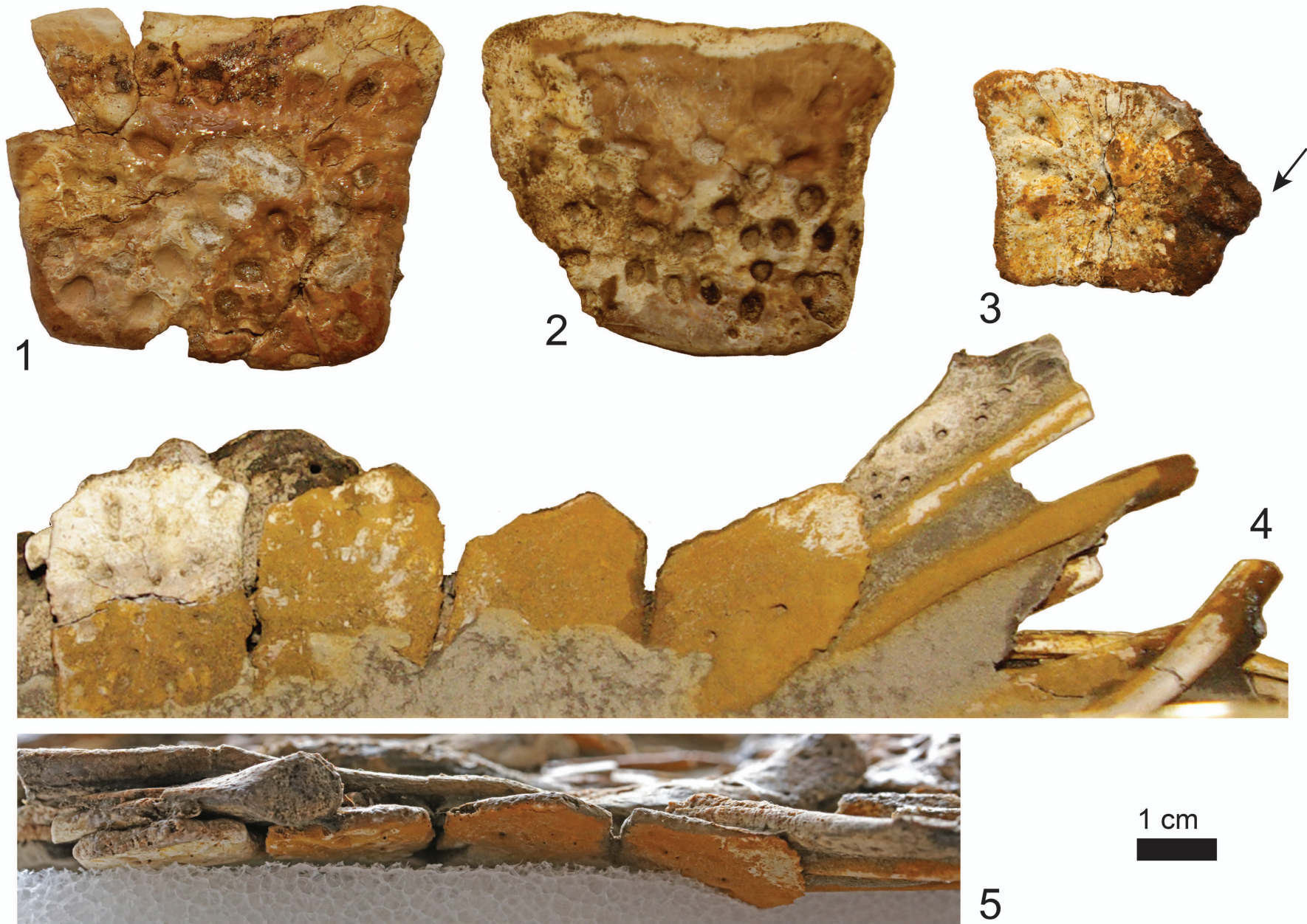

5 
